\title{
RANCANG BANGUN DETEKTOR KEBOCORAN DINI TABUNG GAS LPG MENGGUNAKAN ANALOG GAS SENSOR MQ6 DENGAN DFRDUINO UNO V3.0 BERBASIS LIQUID CRISTAL DISPLAY
}

\section{Rantonius Lumban Gaol dan Sehat simatupang *}

Jurusan Fisika, Fakultas Matematika dan Ilmu Pengetahuan Alam, Universitas Negeri Medan, Indonesia

\begin{abstract}
Abstrak
Penelitian bertujuan untuk merancang bangun detektor kebocoran dini tabung gas LPG menggunakan analog gas sensor MQ6 dengan DFRduino UNO V3.0 berbasis liquid cristal display yang dapat mengetahui status dari tabung gas $L P G$. Detektor kebocoran dini tabung Gas LPG menggunakan sensor MQ-6 dilengkapi dengan Indikator Audiovisual yang terdiri dari LED dan Buzzer. Setting kerja dari indikator dengan syarat, jika konsentrasi gas $\geq 18000$ ppm maka buzzer berbunyi dengan tempo yang cepat, LED merah menyala dan LCD menampilkan status Bahaya dan besaran suhu. Jika konsentrasi gas $\geq 5000 \mathrm{ppm}$ dan konsentrasi gas < 18000 ppm maka buzzer berbunyi dengan tempo yang lambat, LED Kuning menyala dan LCD menampilkan status Waspada dan besaran suhu. Jika konsentrasi gas < 5000 ppm maka buzzer diam, LED Hijau menyala dan LCD menampilkan status Aman dan besaran suhu. Rata-rata suhu ruangan pengujian sampel A sebesar $28,68^{\circ} \mathrm{C}$, sampel B sebesar $28,7^{\circ} \mathrm{C}$ dan sampel $\mathrm{C}$ sebesar $28,1^{\circ} \mathrm{C}$. Hasil dari penelitian ini adalah telah terancangnya detektor kebocoran dini tabung gas LPG yang lebih praktis dan sensitive dibandingkan penelitian sebelumnya. Hal ini terbukti dimana detektor ini menggunakan DFRduino UNO V3.0. Dimana DFRduino UNO V3.0 lebih praktis dan komplit dibandingkan mikrokontroler ATmega 8535 yang digunakan pada penelitian sebelumnya. Detektor ini juga lebih sensitive dari detektor penelitian sebelumnya, hal ini terbukti dari data penelitian, dimana detektor ini mampu mendetaksi kadar gas LPG mulai dari 200 ppm sampai dengan $67000 \mathrm{ppm}$. Sedangkan pada penelitian sebelumnya hanya mampu mendeteksi konsentrasi gas mulai dari 400 ppm sampai dengan 10000 ppm.
\end{abstract}

Kata Kunci : LPG, Analog Sensor MQ6, DFRduino UNO V3.0 Liquid Cristal Displayl, Buzzer.

How to Cite Rita Juliani dan Hengki Sembiring, (2015), Rancang Bangun Detektor Kebocoran Dini Tabung Gas Lpg Menggunakan Analog Gas Sensor Mq6 Dengan Dfrduino Uno V3.0 Berbasis Liquid Cristal Display, Jurnal Einsten Prodi Fisika FMIPA Unimed, 3 (2): 18-22.

*Corresponding author:

E-mail : rantonius@gmail.com 


\section{PENDAHULUAN}

Kebijakan pemerintah dalam melakukan konversi penggunaan energi dari minyak tanah ke gas LPG (Liquefied Petroleum Gas) telah banyak mendorong orang untuk memakai kompor gas LPG sebagai bahan bakar kompor yang digunakan. Seiring kebijakan pemerintah tersebut ternyata banyak menimbulkan masalah. Meskipun kompor gas LPG memiliki kelebihan lebih praktis penggunaannya dari kompor minyak tanah, tetapi masih memiliki kekurangan yaitu bahaya yang ditimbulkannya jika terjadi kebocoran gas yang berakibat pada ledakan dan menimbulkan kebakaran bahkan korban jiwa.

Berdasarkan data BPKN (Badan Perlindungan Konsumen Nasional) hingga bulan Juni 2013, kasus kecelakaan gas LPG terlihat melonjak dari tahun 2007 hingga tahun 2013, ini dikarenakan masih kurangnya pengetahuan dan kepedulian masyarakat tentang cara pemakaian gas LPG yang baik dan benar. (Fahmizal,2013)

Pemakaian dan pendistribusian gas LPG yang tidak sesuai dengan prosedur, dapat mengakibatkan rawannya kebocoran pada tabung gas LPG. Tabung gas LPG yang bocor dapat dengan mudah menimbulkan kebakaran apabila terkena percikan api,namun tabung gas LPG yang bocor tidak akan meledak ataupun terbakar bila tidak terkena percikan api.

Belum adanya penanggulangan dari pemerintah untuk mengatasi kebocoran tabung gas LPG tersebut, maka solusi yang tepat adalah membuat alat pendeteksi kebocoran tabung gas LPG yang dapat mendeteksi kebocoran dini pada tabung gas LPG.Dengan bantuan alat ini maka manusia dapat mengetahui keadaan dari suatu tabung gas, bocor atau tidak.

Salah satu contoh dari alat pendeteksi kebocoran tabung gas LPG adalah detector kebocoran gas LPG menggunakan mikrokontroler Atmega 8535 dan sensor TGS 2610 berbasis LCD,yang diteliti oleh Danur. Berdasarkan penelitian Danur (2007), merancang suatu alat yang dapat mengetahui kebocoran gas terdiri dari sensor TGS2610, mikrokontroler ATMega 8535, buzzer sebagai indikator pemberitahuan dan LCD sebagai media penampilan hasil pendeteksian dari sensor TGS2610. Terdapat tiga kondisi yang ditampilkan pada LCD, yaitu kondisi normal, sedang dan bahaya.

Namun alat ini masih memiliki beberapa kelemahan, adapun kelemahan dari alat ini adalah, Sensor TGS 2610 yang harus dipanaskan terlebih dahulu selama 1menit untuk mengoptimalkan kinerjanya, hanya dapat mendeteksi gas LPG 500-10.000 ppm, pemakaian mikrokontroler Atmega 8535 yang rumit. (Danur,2007)

Dengan demikian, penulis
melalukan menggunakan sensor yang lebih peka dalam mendeteksi kebocoran tabung gas dan kemudahan menggunakan mikrokontroler,karena alat ini diharapkan mempunyai kelebihan antara lain, alat ini menggunakan analog gas sensor MQ6 yang tidak memerlukan pemansan. alat ini dapat mendeteksi 200-100.000 ppm, alat ini menggunakan DFRduino yang lebih kompleks dibandingkan mikrokontroler Atmega 8535. Dimana penggunaan mikrokontroler DFRduino UNO V3.0 tidak perlu menginstal bootloadernya, dengan memasukkan koding program pada Arduino software maka DFRduino UNO secara otomatis menjalankan perintah yang dilisting. Penggunaan kit board DFRduino UNO V3.0, perancangan detektor dini kebocoran tabung gas LPG lebih mudah dalam melisting bahasa perintah dalam menjalankan rangkaian.

Berdasarkan uraian diatas penulis ingin melakukan penelitian lanjutan yang berjudul : "Rancang Bangun Detektor Kebocoran Dini Tabung Gas LPG menggunakan Analog Gas Sensor MQ6 dengan DFRduino UNO V3.0 Berbasis Liquid Cristal Display"

\section{METODE PENELITIAN Tempat dan Waktu Penelitian}

Pelaksanaan penelitian, meliputi perakitan dan pengujian akan dilaksanakan 
di Laboratorium Fisika FMIPA Universitas Negeri Medan selama 2 bulan.

\section{Alat Dan Bahan}

\section{Alat}

Dfrduino uno v3.0,Sensor suhu IC LM35, Driver Java programme, Laptop, Catu daya regulator, Kabel port USB, LCD 2x16, Pin header, sensor gas MQ6, Buzzer.

\section{Bahan}

Resistor, Potensiometer, Saklar, Transistor, Led, Kabel Penghubung.

\section{Diagram Blok Rancangan Detektor}

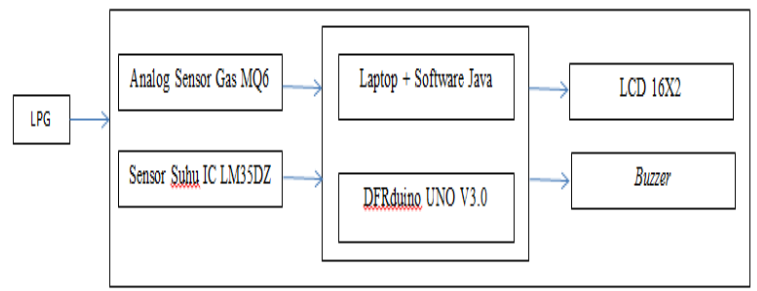

Gambar 1. Diagram Blok Rancangan Detektor

\section{Analisis Data}

Langkah-langkah

dalam menganalisa data, yaitu:

1. Analisis data yang akan disajikan dalam bentuk tabel adalah data hasil pengumpulan data dengan variasi jarak antara sampel gas dengan sensor MQ6 sebagai variable bebas dan data hasil tampilan LCD dan Buzzer.

2. Metode yang digunakan untuk menganalisa hasil penilitian ini adalah metode eksperimen, yaitu dengan menset-up sensor MQ6 terhadap jarak sumber sampel gas, buzzer sebagai indicator adanya polutan gas dan LCD sebagai Indikator penampil suhu ruangan dan status/keadaan.Yang menjadi sampel pada penelitian ini adalah Gas dari Tabung LPG $3 \mathrm{Kg}$.

3. Dalam penelitian ini divariasikan jarak sampel gas dengan sensor MQ6 dan tampilan $L C D$ beserta buzzer yang hasilnya pada tabel .

\section{HASIL DAN PEMBAHASAN}

Hasil Penelitian

Berdasarkan penelitian dari detektor kebocoran dini tabung gas LPG menggunakan DFRduino UNO V3.0 dan sensor gas MQ-6, disimpulkan:

1. Telah dilakukan pembuatan rancangan fisik detektor kebocoran dini tabung gas LPG menggunakan Analog Gas Sensor MQ-6 dengan DFRduino UNO V3.0 berbasis LCD. Rangkaian detektor kebocoran gas LPG yang telah dirancang bekerja dengan baik sesuai dengan bahasa yang disusun. Sensor MQ-6 ini dipengaruhi oleh banyaknya kadar konsentrasi gas dari sampel.

2. Telah dibuat susunan listing program pada sketch Arduino sehingga detektor dapat menjalankan fungsi sesuai dengan kebutuhan dalam penelitian.

3. Detektor kebocoran dini tabung Gas LPG menggunakan sensor MQ-6 dilengkapi dengan Indikator Audiovisual yang terdiri dari LED dan Buzzer. Setting kerja dari indikator dengan syarat, jika konsentrasi gas $(\mathrm{ppm}) \geq 18000$ maka buzzer berbunyi dengan tempo yang cepat, LED merah menyala dan LCD menampilkan status Bahaya dan besaran suhu. Jika konsentrasi gas $(\mathrm{ppm}) \geq 5000$ dan konsentrasi gas (ppm) < 18000 maka buzzer berbunyi dengan tempo yang lambat, LED Kuning menyala dan LCD menampilkan status Waspada dan besaran suhu.Jika konsentrasi gas $(\mathrm{ppm})<5000$ maka buzzer diam, LED Hijau menyala dan LCD menampilkan status Aman dan besaran suhu.

4. Rata-rata suhu ruangan pengujian sampel A sebesar $28,68^{\circ} \mathrm{C}$, sampel B sebesar $28,7^{\circ} \mathrm{C}$ dan sampel $\mathrm{C}$ sebesar $28,1^{\circ} \mathrm{C}$.

\section{Pembahasan}


Berdasarkan gambar 4.4 pada sampel gas elpiji dapat d simpulkan bahwa pada status bahaya terdapat pada 67300ppm- 16900ppm dan pada jarak 0-22 inci. Status waspada terdapat pada konsentrasi 16900ppm-6600ppm dan pada jarak 23-28 inci. Status aman berada pada konsentrasi 4800-2300ppm dan berada pada jarak 29-33 inci.

Berdasarkan gambar 4.5 pada sempel gas kaleng dapat d simpulkan bahwa status bahaya berada pada konsentrasi 64200ppm- 19700ppm dan pada jarak 0-18 inci. Status waspada berada pada konsentrasi 1200ppm6300ppm dan pada jarak 21-24 inci. Status aman berada pada konsentrasi 3100ppm2000ppm dan pada jarank 27-28 inci.

Berdasarkan gambar 4.6 pada sempel gas macis dapat d simpulkan bahwa status bahaya berada pada konsentrasi 32200ppm- 19800ppm dan pada jarak 0-28 inci. Status waspada berada pada konsentrasi 17600ppm6300ppm dan pada jarak 4-6 inci. Status aman berada pada konsentrasi 3200ppm200ppm dan pada jarank 7-9 inci.

Berdasarkan gambar maka pembacaan status aman, waspada dan bahaya tidak konsisten hal ini berhubungan dengan tabel 4.4 dan 4.5 ini di karnakan bahasa pemograman yang berbeda yakni bahasa pemograman pada penelitan Danur adalah bahasa java sedangkan bahasa pemograman pada penelitian ini adalah bahasa pemograman arduino. Dengan demikian yang perlu di perbaiki adalah bahasa pemogramannya.

\section{KESIMPULAN DAN SARAN Kesimpulan}

Berdasarkan hasil penelitian dari detektor kebocoran dini tabung gas LPG menggunakan DFRduino UNO V3.0 dan sensor gas MQ-6, disimpulkan:

1. Telah dilakukan pembuatan rancangan fisik detektor kebocoran dini tabung gas LPG menggunakan Analog Gas Sensor MQ-6 dengan DFRduino UNO
V3.0 berbasis LCD. Rangkaian detektor kebocoran gas LPG yang telah dirancang bekerja dengan baik sesuai dengan bahasa yang disusun. Sensor MQ-6 ini dipengaruhi oleh banyaknya kadar konsentrasi gas dari sampel.

2. Telah dibuat susunan listing program pada sketch Arduino sehingga detektor dapat menjalankan fungsi sesuai dengan kebutuhan dalam penelitian.

3. Detektor kebocoran dini tabung Gas LPG menggunakan sensor MQ-6 dilengkapi dengan Indikator Audiovisual yang terdiri dari LED dan Buzzer. Setting kerja dari indikator dengan syarat, jika konsentrasi gas $(\mathrm{ppm}) \geq 18000$ maka buzzer berbunyi dengan tempo yang cepat, LED merah menyala dan LCD menampilkan status Bahaya dan besaran suhu. Jika konsentrasi gas (ppm) $\geq 5000$ dan konsentrasi gas $(\mathrm{ppm})<18000$ maka buzzer berbunyi dengan tempo yang lambat, LED Kuning menyala dan LCD menampilkan status Waspada dan besaran suhu. Jika konsentrasi gas $(\mathrm{ppm})<5000$ maka buzzer diam, LED Hijau menyala dan LCD menampilkan status Aman dan besaran suhu.

4. Rata-rata suhu ruangan pengujian sampel A sebesar $28,68^{\circ} \mathrm{C}$, sampel B sebesar $28,7^{\circ} \mathrm{C}$ dan sampel $\mathrm{C}$ sebesar $28,1^{\circ} \mathrm{C}$.

\section{Saran}

Untuk perancangan detektor kebocoran dini tabung gas LPG ini lebih baik kedepannya, diharapkan ada perbaikan dan pengembangan untuk mendapatkan detektor gas yang lebih tepat yaitu :

1. Perancangan detektor kebocoran dini tabung gas LPG sebaiknya menggunakan sensor yang memiliki luas penampang yang lebih besar dari sensor MQ-6.

2. Perancangan detektor kebocoran dini tabung gas LPG dengan menggunakan notifikasi melalui 
phone seluler dalam bentuk short message services (sms).

\section{DAFTAR PUSTAKA}

Danur, B., D., (2007). Sistem Pendeteksian Kebocoran Gas LPG Menggunakan Mikrokontroler (Jurnal). Padang : FTI-UNAND dan FT Komputer- Politeknik Negeri Padang.

Fahmizal., (2013). Grafik Data Kasus

Ledakan Tabung Gas Lpg.

http://fahmizaleeits.blogspot.com/t ulisan terkirim dikaitan (tagged) 'grafik data kasus ledakan tabung gas lpg' . di akses 26 mei 2014.

Harja,I.,(2012).Pengertian

Buzzer. http://indraharja.wordpress.com/20 12/01/07/pengertian-buzzer/.

Diposted Tanggal 07 Januari 2012. 